\title{
Article \\ Effect of Processing on the Nutritional Quality of Ilex paraguariensis
}

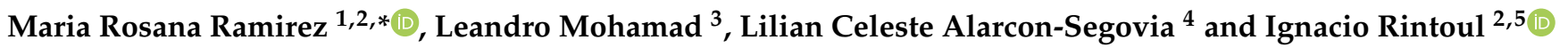 \\ 1 Instituto Universitario de Ciencias de la Salud, Fundación Barceló, Centeno 710, \\ Santo Tome CP 3340, Argentina \\ 2 Consejo Nacional de Investigaciones Científicas Técnicas (CONICET), Buenos Aires C1033AAJ, Argentina; \\ irintoul@santafe-conicet.gov.ar \\ 3 Rock River Laboratory, Parque Tecnológico Litoral Centro, Colectora Ruta Nac, 168, \\ Santa Fe CP 3000, Argentina; leandro.mohamad@rockriverlab.com \\ 4 Núcleo de Innovación Médica, Facultad de Medicina, Universidad María Auxiliadora, \\ Asunción CP 2040, Paraguay; lilian.alarcon@umax.edu.py \\ 5 Instituto de Desarrollo Tecnológico para la Industria Química, Universidad Nacional del Litoral, \\ Colectora Ruta Nac, 168, Santa Fe CP 3000, Argentina \\ * Correspondence: mr.ramirez@conicet.gov.ar
}

check for updates

Citation: Ramirez, M.R.; Mohamad, L.; Alarcon-Segovia, L.C.; Rintoul, I. Effect of Processing on the Nutritional Quality of Ilex paraguariensis. Appl. Sci. 2022, 12, 2487. https://doi.org/ 10.3390/app12052487

Academic Editor: Wojciech Kolanowski

Received: 23 November 2021

Accepted: 20 February 2022

Published: 27 February 2022

Publisher's Note: MDPI stays neutral with regard to jurisdictional claims in published maps and institutional affiliations.

Copyright: () 2022 by the authors Licensee MDPI, Basel, Switzerland. This article is an open access article distributed under the terms and conditions of the Creative Commons Attribution (CC BY) license (https:// creativecommons.org/licenses/by/ $4.0 /)$.

\begin{abstract}
Ilex paraguariensis A.St.-Hil. (IP) is a South American plant. IP-dried leaves have been consumed in the form of infusion by indigenous peoples since pre-Hispanic times. In recent years, $I P$ has gained many beverage markets and new ways of consumption, reaching the category of a global consumer product. A side consequence is the increase in IP crops for the specification of human consumption. This situation is the driving force for the investigation of new uses of $I P$, including feed supplements for livestock and functional food for human consumption. A deep understanding of the influence of processing on the nutritional value of $I P$ is crucial for the development of these alternative products. It is known that the quality and quantity of nutritional compounds occurring in IP depend on the origin, plant condition, and harvest time. However, the effects of the drying method of the leaves and the ageing time of dried leaves on the final IP products deserve further investigation. The present work presents the variation of the nutritional, digestibility, energy, and mineral assets of IP submitted to three different processes: open-air dried and crushed; dried under direct fire and grounded; and dried under direct fire, grounded, and aged for 6 months under controlled conditions. The presence of agrochemical residues and antinutritional factors were also studied. Processing widely influenced the nutritional and digestibility assets of $I P$ leaves. The inorganic content $(\mathrm{K}, \mathrm{Mg}$, $\mathrm{Ca}, \mathrm{P}, \mathrm{Zn}, \mathrm{B}$ and $\mathrm{Fe}$ ) significantly varied among leaves treated using different processes. IP samples dried in open air resulted in the highest \% of crude protein, $\mathrm{Mg}, \mathrm{K}, \mathrm{S}$, and $\mathrm{Mn}$. IP samples dried under direct fire resulted in the highest \% of carbohydrates and Fe. IP samples dried under direct fire and aged for 6 months resulted in the highest \% of digestible matter, $\mathrm{Ca}, \mathrm{P}, \mathrm{Zn}$, and $\mathrm{B}$. The results also showed quality protein levels between 10.03 and $19.06 \%$ of dry matter. The digestibility values showed that IP leaves are suitable for human functional foods and for enriched supplements for livestock feeds. No traces of agrochemicals or antinutritional factors were found.
\end{abstract}

Keywords: Yerba mate; digestibility; nutritional composition

\section{Introduction}

Ilex paraguariensis A.St.-Hil. from the Aquifoliaceae family (IP), is a native tree species of subtropical South America. Its natural distribution occurs in 3\% of the South American territory and covers the region between $21^{\circ}$ and $30^{\circ}$ south latitude and $48^{\circ} 30^{\prime}$ and $56^{\circ} 10^{\prime}$ west longitude [1]. This region includes northeast Argentina, eastern Paraguay, western Uruguay, and south Brazil. IP is only cultivated in its natural habitat where it is perfectly adapted to the geography and biome [2]. This fact leads to the commercial exploitation of IP with minimal use of agrochemicals. 
Yerba Mate is a food product consisting of IP leaves and young stems submitted to the following generic processing sequence: harvesting, roasting, drying, milling, ageing, and packing [3]. The conditions of each of the mentioned steps can greatly vary according to technical, biological, and commercial limitations. Yerba Mate has been largely consumed in the form of warm or cold infusions by the inhabitants of the southern countries of South America [4]. In recent years, Yerba Mate gained many new markets around the world as an active component of energizer drinks and iced teas, among many others [5]. The regular consumption of Yerba Mate has been demonstrated to decrease the risk of developing diabetes mellitus, arteriosclerosis, cardiovascular diseases, osteoporosis, colon cancer, and Parkinson's disease [6]. The discovery of all these benefits and the growing global demand of Yerba Mate-based beverages, infusions, food supplements, and nutraceutics can be identified as the driving forces for the sustained increase in IP cultivated land.

A side effect of this situation is the increase in crops not suitable for commercialization and adulterations [7]. Crops out of international quality specifications and the volatile prices of Yerba Mate can be mentioned as main causes.

In response, Yerba Mate has been considered as a natural, novel feed supplement in livestock production. It has been recommended as feed supplement with the potential for improving feed intake and wool growth in lambs [8] and milk production in dairy cows [9]. It has been also demonstrated that Yerba Mate supplementation during the peri-partum period has positive effects on milk fat, protein concentration, and total solid concentration [10]. Moreover, Yerba Mate supplementation in growing calves and dairy cows improves their lipid metabolism [11] and the fiber and protein degradation in the rumen, reduces ammonia production, and increases protein availability for productive purposes [12]. All these effects have been correlated with the presence of tannins, which increase the availability of proteins and which in turn result in a greater efficiency of feed utilization [13]. These encouraging results pushed the scientific interest in the use of $I P$ leaves as a high-quality nutritional feed supplement in livestock production. Moreover, IP fruits are under investigation for producing value-added compounds. Currently, IP fruits are completely neglected and discharged with no commercial value [14]. Indeed, functional feed supplements have the potential of partial substitution and minimization of the use of many drugs in animal husbandry [15]. However, livestock production demands feed supplements at a very low cost.

Previous studies demonstrated that changes in the cultivation and processing conditions affect the chemical composition and the quality of the nutritional value of Yerba Mate [16]. More specifically, different processes can result in IP products with huge variations in their nutrient content [17-19]. Therefore, the evaluation of the nutritional value of IP treated with different industrial processes is critical to determine the optimal costeffective process required to produce Yerba Mate for human consumption and/or for feed supplement for livestock production. The optimal process is that which maximizes the nutritional value of $I P$ at the minimal cost and the minimal number of processing steps.

In the present work, an extended nutritional, energy, and mineral characterization study of IP submitted to three different processes was carried out and related to the feed requirements of dairy and beef cattle. The occurrence of agrochemicals and anti-nutritional factors was also investigated.

\section{Materials and Methods}

\subsection{Plant Material}

The IP samples were obtained from a cultivated IP field located at the Department of San Ignacio in the Province of Misiones, Argentina. This agro-ecological region has a subtropical climate without a dry season [2]. This region is particularly conducive for commercial exploitation of IP culture [20]. IP samples were withdrawn from a plantation containing a clay-sandy soil known as lateritic soil. This soil is rich in $\mathrm{K}$ and Fe oxides, and the local relief of the plantation permits rain waters to flow without stalling in the soil [1]. 
The collection of samples was carried out according to the following procedure: four parts of $500 \mathrm{~g}$ each were taken from different places in a pile of material containing justharvested, ripe green leaves. Subsequently, these four parts were mixed together to obtain a homogeneous and representative sample of the entire pile of ripe green leaves. Three aliquots of $500 \mathrm{~g}$ were withdrawn from the homogenized sample of ripe green leaves. Then, each of these aliquots were submitted to a different process:

S1: Ripe green leaves were harvested, were naturally dried at room temperature under open-air conditions for two weeks, and were grounded. The fraction trapped between the sieves of a rectangular aperture of $5 \times 70 \mathrm{~mm}^{2}$ and $1 \times 20 \mathrm{~mm}^{2}$ was recovered for subsequent studies.

S2: Ripe green leaves were harvested, were dried under direct fire for a few seconds, and were grounded. The fraction trapped between the sieves of a rectangular aperture of $5 \times 70 \mathrm{~mm}^{2}$ and $1 \times 20 \mathrm{~mm}^{2}$ was recovered for subsequent studies.

S3: Ripe green leaves were harvested, were dried under direct fire for a few seconds, and were grounded. The fraction trapped between the sieves of a rectangular aperture of $5 \times 70 \mathrm{~mm}^{2}$ and $1 \times 20 \mathrm{~mm}^{2}$ was recovered and aged for 6 months at $21 \pm 5{ }^{\circ} \mathrm{C}$ and at a maximum of $60 \%$ relative humidity.

All treated samples were homogenized and size reduced using a cyclonic mill (UDY, USA) equipped with a $1 \times 1 \mathrm{~mm}^{2}$ sieve mesh. The resulting materials were hermetically sealed in plastic bags and stored at $4{ }^{\circ} \mathrm{C}$ until use.

$\mathrm{S} 1, \mathrm{~S} 2$, and S3 are three industrial processes currently applied in the production of IP products. They must be understood as alternative paths to achieve marketable IP products. The selection of the optimal path is carried out with a number of considerations, including the weather condition during harvest time, the urgency level of the customers regarding the delivery of products, production costs, and different quality ranges of IP products, among many others. For example, S1 can be appropriate if the weather is dry during the harvest time and if there are no urgent demands from customers. S1 would not be appropriate if the weather was very humid during the harvest time. In this case, natural drying would demand too much time with certain risks of fungus proliferation. In this case, S2 and S3 would be more appropriate. Conversely, S2 is recommended in case of humid weather and urgent product demands. S3 is recommended in case of humid weather and no urgent demands.

The S1 process can be considered an almost unaltered control sample. S1 processing is a very soft treatment. The great majority of phytochemical studies treat the plants according to S1. Drying in open-air conditions is the usual method for chemical stabilization and the conditioning of plants for scientific studies. Moreover, drying at $25{ }^{\circ} \mathrm{C}$ showed to be comparable to freeze-drying for the preservation of plant properties carried out during experimental studies to assess biomass composition [21,22].

\subsection{Determination of Agrochemical Residues}

Dimethoate is a widely used organophosphate insecticide [23]. Glyphosate is a broad-spectrum systemic herbicide [24]. AMPA is a primary degradation product of glyphosate [25]. AMPA is considered with similar toxicological assets as glyphosate itself [26]. Ammonium glufosinate is also a broad-spectrum herbicide [27]. Dimethoate is not recommended to treat IP fields. However, it is used to control Psyllidae, its principal pest [28]. Conversely, there are no references of the direct use of glyphosate and ammonium glufosinate in IP culture. However, the expansion of soybean culture across the Amazonia is causing close interactions with $I P$ fields. As a consequence, the presence of glyphosate, AMPA, and ammonium glufosinate in IP-based products must be investigated.

Crystalline solid standards of dimethoate (98.0\%), glyphosate (97.0\%), AMPA (98.0\%), and ammonium glufosinate $(97.5 \%)$ were obtained from Dr. Ehrenstorfer GmbH (Augsburg, Germany).

The determination of dimethoate was carried out using the QuEChERS extraction method followed by Liquid Chromatography Triple Quadrupole Mass Spectrometry 
(UHPLC-MS/MS) [29]. The UHPLC-MS/MS system has a detection limit of $10 \mu \mathrm{g} / \mathrm{kg}$ for dimethoate quantification. The determinations of glyphosate, AMPA, and ammonium glufosinate were carried out by derivatization with 9-fluorenylmethylchloroformate (FMOC$\mathrm{Cl}$ (Merck, Darmstadt, Germany), followed by solid phase extraction cleaning (SPE) and UHPLC-MS/MS. The UHPLC-MS/MS system was composed of an Acquity UPLC ${ }^{\circledR}$ liquid chromatograph (Waters, Milford, MA, USA) coupled to a triple quadrupole mass spectrometer equipped with an ESI source able to operate in either the positive or negative-ion mode (TQD, Waters Micromass, UK). Chromatographic and mass spectrometry data handling were performed using MassLynx software v 4.1 (Waters, Manchester, UK). This system also has a detection limit of $10 \mu \mathrm{g} / \mathrm{kg}$ for glyphosate, AMPA, and ammonium glufosinate quantification. Further details about the analytics can be found in [29]. All solvents used in the analytics were HPLC quality with gradient grade $\geq 99.9 \%$ (Cicarelli, Argentina).

\subsection{Microbiological Analysis}

Bacteria, mold, yeast, and their toxins may wreak havoc on nutritional and digestibility assets [30]. They are called "anti-nutritional factors" and may greatly affect consumer health and product performance [30]. For these reasons, the anti-nutritional factors in the $I P$ harvested samples were analyzed. The risk associated with anti-nutritional factors is measured by the count and identification of suspect organisms. In this study, the count and identification of yeasts, mold, and enterobacteria were performed by the standard culture method [31]. The number of yeast and mold colony forming units (cfu) per gram of plant samples required a 5-day incubation. Bacteria measurements counted all the species included in the Enterobacteriaceae family [32]. Enterobacteriaceae were enumerated by means of the most probable number colony counting technique [31,32].

\subsection{Evaluation of Nutritional Assets}

Standard physical, chemical, enzymatic, volumetric, and gravimetric techniques were applied to measure the core nutrients, minerals, and digestibility of S1, S2, and S3. Subsamples were withdrawn from each original sample. The subsamples were used to measure each nutrient separately according to standard recommended techniques.

Crude protein $(\mathrm{CP})$ value is an important indicator for growth and performance. $\mathrm{CP}$ was calculated as a \% of the dry matter (DM) after measuring nitrogen $(\mathrm{N})$ content by GAFTA and ISO methods [33,34]. Soluble protein (SP) is measured as a \% of the CP and determines how much protein is water soluble. $\mathrm{CP}$ solubility helps to determine the available protein. Available $\mathrm{CP}$ is also measured as a \% of the $\mathrm{CP}$ and determines how much of the total $\mathrm{CP}$ is available for digestion. Available $\mathrm{CP}$ is calculated by subtracting the acid detergent fiber (ADF) bound protein. Plant ADF content is a measure of the cellulose and lignin in plant DM. Plant ADF is a good indicator of digestibility. In addition, it defines the amount of fiber needed by milk-producing mammals.

The acid detergent insoluble $\mathrm{CP}$ (ADICP) measures the tightly bound protein that is not available for digestion. ADICP is defined as an ADF bound protein according to ISO 13906. It is expressed as a \% of the DM [35]. Neutral detergent in soluble CP (NDICP) measures the protein that is bound to the neutral detergent fiber fraction (NDF). It is measured according to ISO 16,472 and is expressed as a \% of the DM [36]. NDF is a measure of the cell wall content of plant-based feeds and limits total feed intake in diets with high plant content. Plant ADF is part of the NDF. NDF and ADF contents vary with plant phenotype and plant age. NDF and ADF were measured according to ISO 16,472 [36] and ISO 13,906 [35], respectively. The NDF corrected for ash content (aNDF) is also expressed as a \% of DM. High aNDF values generally occur in plant species with low $\mathrm{CP}$ values [37].

Lignin is a woody fiber linkage. Lignin is not digestible by humans or ruminants. The lignin content is measured using sulfuric acid reagent grade (Biopack, Buenos Aires, Argentina) according to an adapted method based on ISO 13,906, and it is expressed as a \% of DM [35]. The fiber digestibility (NDFD) is expressed as a \% of NDF. NDFD is important for nutritionists to estimate how much fiber can be digested. Fiber digestion times of 24, 30, 
$48,72,120$ and $240 \mathrm{~h}$ were selected to define the extent of total fiber digestion. The NDFD was determined using the "traditional" Goering and Van Soest method (tNDFD) [38] and the standardized Combs-Goeser method (sNDFD) [39]. The part of the fiber that has not been digested after a certain time (uNDF $\mathrm{t}$ ) was expressed as a \% of DM. In particular, uNDF 240 is, by definition, the fraction of fiber that can never be digested and is equated with the indigestible NDF (iNDF).

Non-fibrous carbohydrates (NFCs) are the sugar-related carbohydrates and starches found inside the cell walls of plant tissues. In general, starch is the most important fraction of the NFC. These compounds are nearly 100\% digestible. NFCs are necessary in the intestine for bacterial growth and for the production of high-quality bacterial proteins. However, an excess of NFC could lead to clinical acidosis [40]. The starch content is expressed as a \% of DM and was measured by cleaving the starch molecules into individual glucose molecules and then reading the resulting glucose content.

The ash content is expressed as a \% of DM and was measured by burning the sample according to GAFTA [41] and ISO [42] methods. Ash stems from soil contamination and from minerals within the plant. Fat is a high energy nutrient. The content of fat-like compounds (EE) is expressed as a \% of DM and was measured using an ether extraction method according to GAFTA [43] and ISO [44] methods.

The total minerals were determined by an Inductively Coupled Plasma Mass Spectrometer (ICP-MS) (NexION 2000 ICP Mass Spectrometer, Perking Elmer, Boston, USA). The following elements were determined in the samples: calcium (Ca), magnesium $(\mathrm{Mg})$, sodium $(\mathrm{Na})$, potassium $(\mathrm{K})$, phosphorous $(\mathrm{P})$, manganese $(\mathrm{Mn})$, sulfur $(\mathrm{S})$, zinc $(\mathrm{Zn})$, copper $(\mathrm{Cu})$, and iron $(\mathrm{Fe})$. The analysis was performed in an Atomic Absorption Spectrometer (AAS) (AANALIST 200, Perkin Elmer, USA) according to the standard methods GAFTA [45], ISO [46], and AOAC [47].

Fiber fractions, fiber digestibility, and lignin, among the other parameters described before, were determined using a Fibertec ${ }^{\mathrm{TM}}$ automated system (Gerber Instruments, Effretikon, Switzerland). The Fibertec ${ }^{\mathrm{TM}}$ automated system uses standard reference methods.

The net energy lactation (NEL), the net energy for maintenance (NEM), and the net energy for growth (NEG) account for the energy needed for conservation and milk production, the energy requirements for breathing, walking, etc., and the energy requirement for muscle and bone formation, respectively. They were calculated according to standard procedures $[48,49]$ and are expressed in $\mathrm{Mcal} / \mathrm{kg}$.

\subsection{Feedstuff In Vitro NDF Digestion Procedure}

The digestible energy (DE) and metabolizable energy (ME) concentrations of the feed ingredients are accurately determined through animal experimentation. However, animal experiments are time-consuming and costly. Alternatively, in vitro assays and equations for predicting the energy concentrations of feed ingredients can be used as highly reliable methods [39].

$\mathrm{DE}$ and ME have been reported for Yerba Mate in a number of commercially available forms [50].

$\mathrm{DE}$ and ME determinations were carried out following the traditional Goering and Van Soest method [38] with modifications proposed by Combs and Goeser [51] according to Rock River Laboratory Procedures for Feedstuff in vitro NDF Digestion. This technique determines feedstuff fiber digestibility for use in animal nutrition models. Feed samples were digested for $30 \mathrm{~h}$ using a standard procedure.

Fiber digestion was determined by the difference in fiber content between intact and digested samples, according to Equations (1) and (2):

$$
\begin{gathered}
\mathrm{NDF}=100 \frac{(\mathrm{bag}+\mathrm{res})-(\text { bagcf })}{(\text { bag }+\mathrm{S})-\mathrm{bag}} \\
\mathrm{NDFD}=100 \frac{1-\mathrm{NDF}_{\text {res }}}{\mathrm{NDF}_{0}}
\end{gathered}
$$


Here, S, "bag", and "res" are the weights of the sample, of the bag containing the sample, and of its residue, respectively. $\mathrm{NDF}_{\text {res }}$ is the NDF residue following digestion, and $\mathrm{NDF}_{0}$ is the initial NDF (i.e., digestion time $=0 \mathrm{~h}$ ).

Duplicate subsamples were incubated for each digestion time and then averaged. Reference alfalfa and corn silage standard were included within each in vitro run to ensure precision. Inoculation equipment and stomach fluid collection equipment were used to make these measurements.

\subsection{Statistical Analysis}

Data were expressed as the means of three independent experiments carried out with the duplicates. The errors are indicated as footnotes in the tables of Section 3. A oneway ANOVA with a posteriori Bonferroni's test (InfoStat v.2020) was used to evaluate the significance of results. A probability $p$-value $<0.05$ was considered significant.

\section{Results and Discussion}

\subsection{Agrochemical Analysis}

No residues above $10 \mu \mathrm{g}$ of dimethoate, glyphosate, AMPA, or ammonium glufosinate per $\mathrm{kg}$ of IP DM were detected in S1. The analysis in S1 only is sufficient for agrochemical assessment. S1, S2, and S3 were derived from the same harvested IP pile. Therefore, the agrochemical content (if any) would be the same in S1, S2, and S3. IP is a native South American plant commercially cultivated in its natural habit. Therefore, it is perfectly adapted to its occurring geography, and minimal agrochemical applications are required. In many cases, there is no need to use agrochemicals at all. This fact plays an important role in the minimization of the environmental impact related to the commercial production of IP. Thus, this new information constitutes an important contribution to authorities and scientists for further research, control, and risk analysis purposes.

\subsection{Microbiological Analysis}

Table 1 presents the results of the microbiological analyses of S1, S2, and S3. Very low counts of mold and yeast were observed in relation to the established limits of quantification $(<1000 \mathrm{cfu} / \mathrm{g})$. However, $800 \mathrm{cfu} / \mathrm{g}$ of enterobacteria was detected in S1. These results state that IP processed according to method S1, S2, or S3 is entirely safe in terms of animal health. However, enterobacteria characterization must be carried out to ensure human health standards. The most probable enterobacteria contamination source is attributable to harvesting equipment and transportation. In any case, these results are parallel with those found in the literature [52-54].

Table 1. Microbiological analysis.

\begin{tabular}{cccc}
\hline Species & S1 & S2 & S3 \\
\hline Yeast $[\mathrm{cfu} / \mathrm{g}]$ & 500 & Not detected & 200 \\
\hline Mold $[\mathrm{cfu} / \mathrm{g}]$ & 600 & 20 & 500 \\
\hline Enterobacteria $[\mathrm{cfu} / \mathrm{g}]$ & 800 & 100 & 600 \\
\hline Standard errors. Yeast: \pm 20, Mold: \pm 16, and enterobacteria: \pm 25. & &
\end{tabular}

\subsection{Nutritional Assets}

The nutrient compositions of S1, S2, and S3 are presented in Table 2. Clearly, S1 resulted in humidity levels similar to those reported for fresh, green plants. S2 resulted in a humidity level of $6.51 \%$. The humidity of S3 resulted in a humidity level similar to that of S2. It is evident that the drying under direct fire process is very efficient for reducing the humidity level of IP. Moreover, it is also evident that the ageing process does not significantly affect the humidity level of $I P$. 
Table 2. Nutrient composition of IP submitted to different processes.

\begin{tabular}{|c|c|c|c|c|}
\hline \multicolumn{2}{|c|}{ Nutritional Assets } & \multirow{2}{*}{$\begin{array}{c}\text { S1 } \\
56.30\end{array}$} & \multirow{2}{*}{$\begin{array}{c}\text { S2 } \\
93.49\end{array}$} & \multirow{2}{*}{$\begin{array}{c}\text { S3 } \\
93.74\end{array}$} \\
\hline Dry material & [\%] & & & \\
\hline Humidity & [\%] & 43.70 & 6.51 & 6.26 \\
\hline Crude Protein & {$[\% \mathrm{DM}]$} & 22.07 & 11.63 & 10.88 \\
\hline $\begin{array}{l}\text { Crude Protein } \\
\text { Available }\end{array}$ & {$[\% \mathrm{CP}]$} & 19.06 & 10.78 & 10.03 \\
\hline ADICP & {$[\% \mathrm{DM}]$} & 3.01 & 0.85 & 0.85 \\
\hline NDICP & {$[\% \mathrm{DM}]$} & 7.51 & 1.38 & 1.54 \\
\hline ADF & {$[\% \mathrm{DM}]$} & 27.33 & 27.22 & 29.61 \\
\hline aNDF & {$[\% \mathrm{DM}]$} & 39.76 & 34.55 & 37.82 \\
\hline Fat (EE) & {$[\% \mathrm{DM}]$} & 0.28 & 4.17 & 2.77 \\
\hline Ash & [\% DM] & 7.95 & 6.08 & 6.16 \\
\hline Lignin & {$[\% \mathrm{DM}]$} & 25.24 & 11.17 & 15.98 \\
\hline Starch & {$[\% \mathrm{DM}]$} & 1.78 & 2.94 & 2.44 \\
\hline NDFD 30\% NDF & {$[\% \mathrm{aNDF}]^{*}$} & 6.82 & - & - \\
\hline uNDF 30 & {$[\% \mathrm{DM}] *$} & 41.47 & - & - \\
\hline uNDF30om & {$[\% \mathrm{DM}] *$} & 37.36 & - & - \\
\hline NFC & {$[\% \mathrm{DM}]$} & 37.45 & 44.95 & 43.91 \\
\hline DCAD & [meq/100 g] & 14.77 & 22.79 & 24.79 \\
\hline \multicolumn{5}{|c|}{ NRC 2001 Energy Calculations Dairy } \\
\hline NDT $1 X$ & {$[\% \mathrm{DM}]$} & 49.23 & 63.35 & 56.33 \\
\hline ENL 3X & {$[\mathrm{Mcal} / \mathrm{kg}]$} & 1.144 & 1.423 & 1.267 \\
\hline ENG & {$[\mathrm{Mcal} / \mathrm{kg}]$} & 0.360 & 0.901 & 0.642 \\
\hline ENM & {$[\mathrm{Mcal} / \mathrm{kg}]$} & 0.903 & 1.493 & 1.207 \\
\hline ME 3X NRC2001 & {$[\mathrm{Mcal} / \mathrm{kg}]$} & 1.897 & 2.287 & 2.073 \\
\hline ME 1X NRC2001 & {$[\mathrm{Mcal} / \mathrm{kg}]$} & 1.897 & 2.386 & 2.073 \\
\hline
\end{tabular}

Errors within 5\% of mean values. ${ }^{*}$ NDF results according to [51]

All samples presented an available CP higher than $8 \%$. This value is the minimum required value for supporting bacterial growth in a cow rumen. These data can also be compared with previously reported CP content of cereal grains (8-10\%), corn (4-5\%), and sorghum (4-5\%) [55]. Therefore, IP is demonstrated to have a high potential as a protein source for animal feeds. Along with $\mathrm{N}$, it can contribute to the increase in bacterial growth and to the synthesis of microbial proteins. S1 resulted in 50\% higher CP content than S2. Additionally, S2 resulted in CP content slightly higher than that of S3. However, the available CP resulted in $86.4 \%, 92.7 \%$, and $92.2 \%$ of the total CP content in S1, S2, and S3, respectively. It is interesting to note that the reduction in $\mathrm{CP}$ content as a consequence of the drying under direct fire process mainly affected the non-available protein. Indeed, ADICP and NDICP were significantly higher in S1 than in S2 and S3. NDICP is the main protein fraction in several plant protein sources and is associated with the cell wall structure. The rapidly degradable fraction of NDICP is generally small. The NDICP composition of S1 was higher than the NDICP value for alfalfa (2.44-3.32\%) [55]. The NDICP composition of S2 was below the NDICP value for alfalfa. Moreover, ADICP values for S2 and S3 resulted within the reported ranges of IP [55]. Plant materials damaged by an excess of temperature usually have high ADICP values. It must be interpreted as a protein fraction that is not available for fat and milk production or for physiologic maintenance. ADICP resists rumen degradation and generally does not provide amino acids in the small intestine [56]. 
IP concentrations of ADICP were lower in S3 than in S2 as a consequence of the ageing process. However, the ADICP for S1 was superior to the traditional threshold of $10 \%$ of CP frequently used to define severely heat-damaged hays. This result can be associated with the high environmental temperatures recorded in the region during harvest and transport.

IP samples resulted in a lower ADF than corn silage, hay, or haylage ( $45 \%$ to $60 \%$ ). Additionally, IP presents ADF values within the range reported for other tree species such as Acacia millenaria (28.5\%), Eritrhins poeppigiana (28.8\%), Guazuma ulmifolia $(29.5 \%)$, and Bahinia ungulate (26.5\%) [57]. Feed from trees generally presents higher digestibility than feed from vegetables. Tree foliage generally contains fewer structural elements, such as lignin, cellulose, and hemicelluloses, and less $\mathrm{N}$ than vegetables [57]. It is important to state that the present work reports IP ADF for the first time. The aNDF results of IP samples are similar of that reported for forage trees, such as Tithonia diversifolia $(35.3 \%)$, Acacia millenaria (42.7\%), Eritrhins poeppigiana (43-48\%), Guazuma ulmifolia (42.5\%), and Bahinia ungulate $(42.4 \%)$ [57]. The relatively low NDF and ADF contents in IP samples make them apt for inclusion in ruminant diets $[8,12]$.

The amount of fat in S2 was nearly 15 times higher than that of $\mathrm{S} 1$ as a consequence of drying under direct fire instead of open air. Additionally, the amount of fat in S2 was 1.5 times lower than S3 as a consequence of the ageing process. The chemical reactions involved in these transformations are not included in the present work and are to be the subject of another study.

$\mathrm{S} 1$ resulted in lower lignin values than that of mature foliage. This is normal, since sampling was carried out during the harvest period and included new foliage and twigs. Interestingly, the lignin content of S2 was 44\% lower than that of S1 and 43\% lower than that of S3. The use of IP in livestock diets probably do not affect digestibility or forage intake in contrast to inputs with high lignin content [9]. This argument is supported by results reported for other tree species with low lignin content, such as Bahunia cheilantha (15.3 to $9.1 \%)$, L. leucocephala (11.65\%), and Mimosa caesalpiniifolia (11\%) [57].

IP samples presented a very low starch/NFC ratio compared to other forages. These values provide the necessary bacterial feed in the rumen while avoiding acidosis. This fact makes the $I P$ very suitable as a forage for ruminants.

The decrease in lignin content is related to an increase in the ADICP value. This result is parallel to some investigations $[58,59]$. The observed results may be related to an intense proteolytic activity in the plant, to the action of drying under the direct fire process, or to the high environmental temperatures recorded in the region during harvest and transport.

S1 digestibility values resulted in NDFDs of $30 \% \mathrm{NDF}=6.82 \%$, uNDF $=41.47 \%$, and $\mathrm{uNDF} 30 \mathrm{om}=37.36 \%$. It demonstrated a high effective degradability of NDF by L. divaricata in the present study. S2 and S3 resulted in a low humidity level that impaired the digestibility studies.

The NFCs are necessary to cover the energy needs of the animals and the growth of microorganisms in the rumen. Some authors suggest optimal NFC levels from 32 to $38 \%$ of $\mathrm{DM}$ in diets containing high amounts of sugar and starch, such as barley grains and corn. NFC levels from 38 to $42 \%$ are reported in diets containing hay and sub-products of corn and soy [58].

The NFC value for $\mathrm{S} 1$ was $37.45 \%$, which is within the literature's reported ranges. Starch is the most important fraction of the NFC. The starch content of S1 and S2 were 1.78\% and $2.94 \%$, respectively. These data indicate a possible advantage of the use of $L$. divaricata in ruminants. A more efficient use of the degradable protein in the rumen is expected due to the reported amount of non-structural carbohydrates measured in this shrub. This improvement in energy intake facilitates ruminal balance and promotes the synthesis of microbial proteins.

Dietary Cation-Anion Difference (DCAD) manipulation is a useful tool to promote the production of lactating cows and to prevent metabolic disorders during peripartum. Optimal DCADs are reported as around $38 \mathrm{meq} / 100 \mathrm{~g}$ of DM. Table 2 presents the DCAD values in IP samples. They range from 14.77 to $24.79 \mathrm{meq} / 100 \mathrm{~g}$ for S1 and S3, respectively. 
These values are lower than the optimal DCAD content. However, a diet with such DCAD levels can be successful if balanced with $\mathrm{Ca}$, a double charged cation that can be used to balance the DCAD.

Forage NDT is often calculated from forage ADF. IP samples range from $49.23 \%$ to $63.35 \%$ NDT for S1 and S2, respectively. This result is slightly lower than the NDT value reported for corn silage and greater than that of hay crops. An important effect of the drying process on NDT content was observed. The NDT content in S1 was 18\% higher than the NDT content in S2 and S3 samples.

The energy content of $I P$ was also investigated. NEL was $1.144,1.423$, and $1.267 \mathrm{Mcal} / \mathrm{kg}$ for S1, S2, and S3, respectively. The ENG ratio ranged from $0.215 \%$ to $0.901 \%$ with a mean value of $0.5295 \%$. This ratio was found to be lower than the previously reported literature [59]. Calculated ENM values of in vitro samples were 0.903, 1.493, and 1.207 Mcal/ kg for S1, S2, and S3, respectively. Calculated 3X NRC2001 ME and 1X NRC2001 ME were $1.897,2.287,2.073 \mathrm{Mcal} / \mathrm{kg}$ for S1, S2, and S3, respectively. These results indicate a very high level of ME of IP submitted to the S1, S2, and S3 industrial processes.

The results in Table 2 also show the potential of IP for human nutrition. The benefits of IP consumption are usually related to its content of vitamins, antioxidants, and stimulants. These oligo-components are not investigated in the present contribution, and their effects can be consulted in [6]. Moreover, the infusion way of consumption of IP-based products contributes to human nutrition with just $12 \mathrm{~g}$ of carbohydrates, $2 \mathrm{~g}$ of soluble proteins and 60 calories per $100 \mathrm{~g}$ of IP DM [6]. Consequently, IP infusion may not be considered an abundant source for energy and protein intake for humans.

\subsection{Mineral Content}

The mineral content of S1, S2, and S3 are presented in Table 3. Macro-minerals and oligo-minerals are those bioelements needed in relatively large and small amounts, respectively. It is important to discuss these results comparing the mineral content of IP samples against NRC recommendations [60] and alternative livestock feed supplements.

Table 3. Mineral content in $I P$, NRC recommendations, and alternative livestock feed supplements.

\begin{tabular}{cccccccc}
\hline \multicolumn{2}{c}{ Elements } & S1 & S2 & S3 & NRC & MG & $\begin{array}{c}\text { Mineral Content in Common Feed } \\
\text { Supplements }\end{array}$ \\
\hline $\mathrm{Ca}$ & {$[\%]$} & 0.58 & 0.63 & 0.75 & $0.43-0.66$ & 0.34 & RGT, corn, sunflower, flax: 0.06-0.38 \\
\hline $\mathrm{P}$ & {$[\%]$} & 0.11 & 0.12 & 0.13 & $0.28-0.41$ & 0.14 & RGT: 0.26, corn: 0.22 \\
\hline $\mathrm{Mg}$ & {$[\%]$} & 0.62 & 0.45 & 0.49 & $0.20-0.25$ & 0.26 & RGT: 0.16, corn in plant: 0.14 \\
\hline $\mathrm{K}$ & {$[\%]$} & 1.62 & 1.31 & 1.43 & $0.90-1.00$ & 0.17 & barley, sunflower, sorghum, wheat: $0.76-1.08$ \\
\hline $\mathrm{Na}$ & {$[\%]$} & $\mathrm{ND}$ & $\mathrm{ND}$ & $\mathrm{ND}$ & $\sim 0.18$ & 0.04 & Corn: 0.06 \\
\hline $\mathrm{S}$ & {$[\%]$} & 0.20 & 0.10 & 0.12 & $\sim 0.20$ & - & PGT: 0.15, corn in plant: 0.20 \\
\hline $\mathrm{Cl}$ & {$[\%]$} & 0.52 & 0.16 & 0.16 & $\sim 0.20$ & - & Corn: 46 \\
\hline $\mathrm{Zn}$ & {$[\mathrm{ppm}]$} & 64 & 64 & 72 & 40 & 34 & Corn: 10 \\
\hline $\mathrm{Mn}$ & {$[\mathrm{ppm}]$} & 3329 & 1861 & 1599 & 40 & 467 & Corn: 13 \\
\hline $\mathrm{Cu}$ & {$[\mathrm{ppm}]$} & 11 & 8 & 9 & 10 & 7 & Corn: 48 \\
\hline $\mathrm{Fe}$ & {$[\mathrm{ppm}]$} & 199 & 299 & 264 & 50 & 695 & Plant matter: $1-500$ \\
\hline $\mathrm{Al}$ & {$[\mathrm{ppm}]$} & 440 & 422 & 413 & - & - & Corn: 5, corn in plant: $10-20$ \\
\hline $\mathrm{B}$ & {$[\mathrm{ppm}]$} & 71 & 63 & 71 & - & - & $0.2-2$ \\
\hline
\end{tabular}

Elements: expressed as \% (or ppm) of given element in the ash. Errors within 5\% of mean values. ND: Not detected. RGT: RYE GRASS TAMA.

Ca is the most abundant mineral in a cow's body. The NRC recommendations are defined by the Ca needs of lactating dairy cattle and dairy cattle. The Ca content in IP samples was higher than the Ca content recommended by the NRC. It also resulted in 
higher than that in Misiones grassland, RYE GRASS TAMA, corn in plant, sunflower, and flax-based feed supplements.

The Mesopotamian region of Argentina, including the Province of Misiones, is characterized by soils with less than $5 \mathrm{ppm}$ of $P$. The low amount of $P$ in the soil is reflected in the low content of this element in natural grasslands. The amount of P in IP samples is nearly half of the NRC recommendation. However, it is comparable to that of the Misiones grasslands.

The Mg content in IP samples is between two and three times higher than NRC recommendations and nearly four times higher than the $\mathrm{Mg}$ content found in Misiones grasslands, RYE GRASS TAMA, and corn-in-plant-based feed supplements.

$\mathrm{K}$ is the third most abundant bioelement in a cow's body. The $\mathrm{K}$ content in IP samples and the Misiones grasslands are comparable. Both greatly exceed the NRC recommendations and alternative feed supplements, such as oats, barley, sunflower, flax, garnetiferous sorghum, and wheat. However, it must be controlled. High levels of $\mathrm{K}$ in spring pastures and silages have been reported to cause grass tetanus and hypomagnesia in lactating cattle $[61,62]$.

The NRC recommendation for S is to be nearly $0.20 \%$ of the ash. In addition, an N/S ratio of around 12 is also recommended. The $S$ content of $I P$ samples ranged from $0.20 \%$ for $\mathrm{S} 1$ to $0.10 \%$ for $\mathrm{S} 2$. This is equivalent to the $\mathrm{S}$ content found in corn in plant and a little lower than that in RYE GRASS TAMA. The $S$ content in IP samples can be considered within specification. Supplemental S should not be required in IP based rations.

$\mathrm{Na}$ is needed by the cow for maintaining osmotic regulation of body fluids. Na can be a limiting nutrient in the diet. Therefore, salt is commonly supplemented to dairy cows. Na was not detected in any of the IP samples. Na content in the grasslands of Misiones is also very low. This deficiency could be corrected by adequate salt supplementation and should be provided to dairy cattle on pastures to ensure that they meet their needs for $\mathrm{Na}$.

The Fe content in the Misiones grassland is more than double than the Fe content found in IP samples. However, Fe content in IP samples exceeds the NRC recommendations by 4 to 6 times. The Fe content in IP samples and legume pastures are quite similar. The $\mathrm{Cu}$ content in IP samples is comparable to that of the Misiones grassland and the NRC recommendations. The Mn content in IP samples is more than 40 times the NRC recommendation, and 3 times the Mn content found in Misiones grasslands. The $\mathrm{Zn}$ content in IP samples is significantly higher than the $\mathrm{Zn}$ content of the Misiones grassland and the NRC recommendations. Aluminum is a non-essential element. Al resulted in important concentrations in IP samples. However, it is several orders of magnitude lower than the safe limits established for cattle and other animals. In any case, the occurrence of $\mathrm{Al}$ in IP samples might deserve further investigations for possible health implications and the biogeochemical reasons for its strong presence. Finally, in vitro animal and human investigations have shown that B is a bioactive element [63]. However, it has received little attention in ruminant nutrition. This element is of low toxicity to cattle and is not completely absorbed by the gastrointestinal tract. However, the presence of $\mathrm{B}$ increases the absorption of $\mathrm{Ca}$ and $\mathrm{Mg}$ [63]. Therefore, $\mathrm{B}$ is necessary to avoid hypocalcemia in cows.

The elemental composition of IP samples exceeds the NRC recommendations except for the content of $\mathrm{P}$ and $\mathrm{Na}$. The results observed in this study are within the normal range of forage resources of the temperate region of South America.

The mineral content of IP-based products provides a set of crucial elements for human metabolism. In particular, the high amounts of $\mathrm{Ca}, \mathrm{K}, \mathrm{Mg}$, and $\mathrm{Zn}$ may contribute to the maintaining of the bone structure, the proper functioning of the heart, the protein assimilation, and the reinforcement of the immunitary system, respectively.

\section{Conclusions}

$I P$ in the form of ripe green leaves, naturally dried at room temperature under open-air conditions for two weeks and crushed (S1 sample) resulted in the highest level of crude protein, $\mathrm{Mg}$, K, S, and $\mathrm{Mn}$, when compared against S2 and S3 alternative processes. S1 also 
presented a high level of digestible NFC and reached $49.23 \%$ of digestible dry matter. These facts may justify the suggestion for the use of $I P$ treated according to S1 as feed supplement in livestock exploitations. They also present attractive mineral compositions for their use as food ingredients for human consumption.

$I P$ in the form of ripe green leaves, dried under direct fire for a few seconds and finely grounded (S2 sample) and ripe green leaves harvested and dried under direct fire for a few seconds then grounded and aged for 6 months at $21^{\circ} \mathrm{C}$ and at a maximum of $60 \%$ of relative humidity (S3 sample) resulted in a very similar nutritional quality. Both drying processes ultimately resulted in a loss of nutritional quality with respect to the natural drying process. However, ageing time does not have a strong effect on the nutritional quality of IP. S2 resulted in the highest \% of carbohydrates and Fe, and S3 resulted in the highest $\%$ of digestible matter, $\mathrm{Ca}, \mathrm{P}, \mathrm{Zn}$, and $\mathrm{B}$, when compared against their corresponding alternative processes.

The results also show the quality of protein levels between 10.03 and $19.06 \%$ of dry matter. The digestibility values show that all treated IP leaves are suitable for human functional foods and enriched supplements for livestock feeds.

Although these results are promising, a complete cost-benefit analysis is required. Any potential benefit of the use of IP as feed for livestock must be balanced with production costs. Further research may also consider the optimization of processing technologies to enhance bioactive compounds for use in foods, crops, cosmetics, nutraceuticals, and supplements to support human health.

Author Contributions: Conceptualization, M.R.R. and I.R.; methodology, M.R.R. and L.M.; software, L.C.A.-S.; validation, M.R.R., L.M. and I.R.; formal analysis, I.R.; investigation, M.R.R.; resources, M.R.R., L.C.A.-S. and I.R.; data curation, M.R.R. and I.R.; writing-original draft preparation, M.R.R.; writing-review and editing, I.R.; visualization, I.R.; supervision, M.R.R.; project administration, M.R.R.; funding acquisition, M.R.R., L.C.A.-S. and I.R. All authors have read and agreed to the published version of the manuscript.

Funding: This research was funded by the Instituto Nacional de la Yerba Mate (INYM), Argentina grant number: Proy Prasy. Res. N $101 / 19$ and the APC was funded by the Universidad Maria Auxiliadora and Ignacio Rintoul.

Institutional Review Board Statement: Not applicable.

Informed Consent Statement: Not applicable.

Acknowledgments: This work was supported by Grant PRASY from the INYM, Argentina, and by the UMAX, Paraguay. We thank Gustavo Moya for his assistance in the laboratory analysis.

Conflicts of Interest: The authors declare no conflict of interest.

$\begin{array}{ll}\text { Abbreviations } \\ \text { CP } & \text { crude protein } \\ \text { DM } & \text { dry matter } \\ \text { SP } & \text { soluble protein } \\ \text { ADICP } & \text { acid detergent insoluble CP } \\ \text { NDICP } & \text { neutral detergent insoluble CP } \\ \text { ADF } & \text { acid detergent fiber fraction } \\ \text { NDF } & \text { neutral detergent fiber fraction } \\ \text { CP } & \text { crude protein } \\ \text { DM } & \text { dry matter } \\ \text { SP } & \text { soluble protein } \\ \text { ADICP } & \text { acid detergent insoluble CP } \\ \text { NDICP } & \text { neutral detergent insoluble CP } \\ \text { ADF } & \text { acid detergent fiber fraction } \\ \text { NDF } & \text { neutral detergent fiber fraction }\end{array}$




$\begin{array}{ll}\text { aNDF } & \text { ash corrected NDF } \\ \text { NFC } & \text { non-fibrous carbohydrates (sugars + starch) } \\ \text { NDFD } & \text { fiber digestibility } \\ \text { tNDFD } & \text { fiber digestibility determined by traditional method } \\ \text { sNDFD } & \text { fiber digestibility determined by standard method } \\ \text { uNDF t } & \text { non-digestible fiber at time t } \\ \text { uNDF 240 } & \text { fraction of fiber cannot be digested } \\ \text { iNDF } & \text { indigestible NDF (iNDF = uNDF 240) } \\ \text { EE } & \text { content of fat-like compounds } \\ \text { DE } & \text { digestible energy } \\ \text { ME } & \text { metabolizable energy } \\ \text { IP } & \text { Ilex paraguariensis A.St.-Hil. } \\ \text { AMPA } & \text { aminomethylphosphonic acid } \\ \text { FMOC-Cl } & \text { 9-fluorenylmethylchloroformate } \\ \text { UHPLC-MS/MS } & \text { Chromatography Triple Quadrupole Mass Spectrometry } \\ \text { SPE } & \text { solid phase extraction cleaning } \\ \text { ICP-MS } & \text { Inductively Coupled Plasma Mass Spectrometer } \\ \text { AAS } & \text { Atomic Absorption Spectrometry }\end{array}$

\section{References}

1. Oliveira, Y.M.; Rotta, E. Área de distribuição natural da erva-mate (Ilex paraguarensis St. Hil). In Seminario Sobre Atualidades e Perspectivas Florestais. Silvicultura da Erva-Mate (Ilex paraguariensis); EMBRAPA-CNPF: Curitiba, Brazil, 1985; Volume 10, pp. 17-36.

2. Reissmann, C.B.; Radomski, M.I.; de Quadros, B.R.M. Chemical composition of Ilex Paraguariensis St. Hil. under different management conditions in seven localities of Paraná State. Braz. Arch. Biol. Technol. 1999, 42, 2. [CrossRef]

3. Heck, C.I.; de Mejia, E.G. Yerba Mate Tea (Ilex paraguariensis): A comprehensive review on chemistry, health implications, and technological considerations. J. Food. Sci. 2007, 72, R138-R151. [CrossRef] [PubMed]

4. Navajas, P.; Mac Donnel, M. Caá Porá: El Espíritu de la Yerba Mate, Una Historia del Plata; Establecimiento Las Marías: Corrientes, Argentina, 2013.

5. Samoggia, A.; Landuzzi, P.; Vicién, C.E. Market Expansion of Caffeine-Containing Products: Italian and Argentinian Yerba Mate Consumer Behavior and Health Perception. Int. J. Environ. Res. Public Health 2021, 18, 8117. [CrossRef] [PubMed]

6. Lutomski, P.; Gozdziewska, M.; Florek-Luszczki, M. Health properties of Yerba Mate. Ann. Agric. Environ. Med. 2020, $27,310-313$. [CrossRef] [PubMed]

7. Dallago, R.M.; Valduga, A.T.; Di Luccio, M.; Benin, S.; Tres, M.V. Analysis of volatile compounds of Ilex paraguariensis A.St.-Hil. and its main adulterating species Ilex theizans Mart. ex Reissek and Ilex dumosa Reissek. Ciênc. Agrotec. 2011, 35, 1166-1171. [CrossRef]

8. Po, E.; Horsburgh, K.; Raadsma, H.W.; Celi, P. Yerba Mate (Ilex paraguarensis) as a novel feed supplement for growing lambs. Small. Rumin. Res. 2012, 106, 131-136. [CrossRef]

9. Celi, P.; Raadsma, H.W. Effects of Yerba Mate (Ilex paraguariensis) supplementation on the productive performance of dairy cows during mid-lactation. Anim. Prod. Sci. 2010, 50, 339-344. [CrossRef]

10. Po, E.; Xu, Z.; Celi, P. The Effect of Yerba Mate (Ilex paraguarensis) supplementation on the productive performance of dorper ewes and their progeny. Asian-Australas. J. Anim. Sci. 2012, 25, 945-949. [CrossRef]

11. Celi, P.; Robinson, A. Effects of Yerba Mate (Ilex paraguariensis) supplementation on the performance of dairy calves. Anim. Prod. Sci. 2010, 50, 376-381. [CrossRef]

12. Hartemink, E.; Giorgio, D.; Kaur, R.; Di Trana, A.; Celi, P. The effect of yerba mate (Ilex Paraguariensis) supplementation on nutrient degradability in dairy cows: An In sacco and In vitro study. Asian-Australas. J. Anim. Sci. 2015, 28, 1606-1613. [CrossRef]

13. Barbato, O.; Holmes, B.; Filipescu, I.E.; Celi, P. Dietary supplementation of Yerba Mate (Ilex paraguariensis) during the dry period improves redox balance in lactating dairy cows. Antioxidants 2019, 8, 38. [CrossRef] [PubMed]

14. Fernandes, C.E.F.; Scapinello, J.; Bohn, A.; Boligon, A.A.; Athayde, M.L.; Magro, J.D.; Palliga, M.; Oliveira, J.V.; Tres, M.V. Phytochemical profile, antioxidant and antimicrobial activity of extracts obtained from erva-mate (Ilex paraguariensis) fruit using compressed propane and supercritical $\mathrm{CO}_{2}$. J. Food Sci. Technol. 2017, 54, 98-104. [CrossRef]

15. Weibel, M.I.; Badano, J.M.; Rintoul, I. Technological evolution of hormone delivery systems for estrous synchronization in cattle. Int. J. Livest. Res. 2014, 4, 20-40. [CrossRef]

16. Isolabella, S.; Cogoi, L.; Lopez, P.; Anesini, C.; Ferraro, G.; Filip, R. Study of the bioactive compounds variation during yerba mate (Ilex paraguariensis) processing. Food Chem. 2010, 122, 695-699. [CrossRef]

17. Lewicki, P.P. Design of hot air drying for better foods. Trends Food Sci. Technol. 2006, 17, 153-163. [CrossRef]

18. Passardi, R.L.; Schvezov, C.E.; Schmalko, M.E.; Gonzalez, A.D. Drying of Ilex paraguariensis Saint Hilaire by microwave radiation. Dry. Technol. 2006, 24, 1437-1442. [CrossRef]

19. Westphalen, D.J.; Angelo, A.C.; Rossa, U.B.; Bognola, I.A.; Martins, C.E.N. Impact of different silvicultural techniques on the productive efficiency of Ilex paraguariensis A. St. Hill. Agrofor. Syst. 2020, 94, 791-798. [CrossRef] 
20. Barbosa, J.Z.; Motta, A.C.V.; Consalter, R.; Poggere, G.C.; Santin, D.; Wendling, I. Plant growth, nutrients and potentially toxic elements in leaves of yerba mate clones in response to phosphorus in acid soils. An. Acad. Bras. Cienc. 2018, 90, 557-571. [CrossRef] [PubMed]

21. Silva, A.F.R.; Helena Abreu, H.; Silva, A.M.S.; Cardoso, S.M. Effect of oven-drying on the recovery of valuable compounds from Ulva rigida, Gracilariasp. and Fucus vesiculosus. Mar. Drugs 2019, 17, 90. [CrossRef]

22. Chan, J.C.C.; Cheung, P.C.K.; Ang, P.O. Comparative studies on the effect of three drying methods on the nutritional composition of seaweed Sargassum hemiphyllum (Turn.) C. Ag. J. Agric. Food Chem. 1997, 45, 3056-3059. [CrossRef]

23. Dauterman, W.C.; Viado, G.B.; Casida, J.E.; O'Brien, R.D. Insecticide residues, persistence of dimethoate and metabolites following foliar application to plants. J. Agric. Food Chem. 1960, 8, 115-119. [CrossRef]

24. Green, J.M. Review of glyphosate and als-inhibiting herbicide crop resistance and resistant weed management. Weed Technol. 2007, 21, 547-558. [CrossRef]

25. Grandcoin, A.; Piel, S.; Baures, E. AminoMethylPhosphonic acid (AMPA) in natural waters: Its sources, behavior and environmental fate. Water Res. 2017, 117, 187-197. [CrossRef] [PubMed]

26. Myers, J.P.; Antoniou, M.N.; Blumberg, B.; Carroll, L.; Colborn, T.; Everett, L.G.; Hansen, M.; Landrigan, P.J.; Lanphear, B.P.; Mesnage, R.; et al. Concerns over use of glyphosate-based herbicides and risks associated with exposures: A consensus statement. Environ. Health 2016, 15, 19. [CrossRef] [PubMed]

27. Takano, H.K.; Dayan, F.E. Glufosinate-ammonium: A review of the current state of knowledge. Pest. Manag. Sci. 2020, 76, 3911-3925. [CrossRef]

28. Schmalko, M.E.; Laura, A.; Ramallo, L.A.; Ferreira, D.; Berlingheri, R.D. Dimethoate degradation in plants and during processing of yerba maté leaves. Braz. Arch. Biol. Technol. 2002, 45, 419-422. [CrossRef]

29. Demonte, L.D.; Michlig, N.; Gaggiotti, M.; Adam, C.G.; Beldomenico, H.R.; Repetti, M.R. Determination of glyphosate, AMPA and glufosinate in dairy farm water from Argentina using a simplified UHPLC-MS/MS method. Sci. Total Environ. 2018, 645, 34-43. [CrossRef]

30. Goeser, J. The anti-nutrition factor in dairy cattle. Progress. Dairym. 2015, 16, 116-118.

31. Beachat, L.R.; Cousin, M.A. Yeasts and molds. In Compendium of Methods for the Microbiological of Foods, 4th ed.; Frances Pouch Downes Keith Ito: Washington, DC, USA, 2001; pp. 209-215.

32. Morton, R.D. Aerobic Plate Count. In Compendium of Methods for the Microbiological of Foods, 4th ed.; Frances Pouch Downes Keith Ito: Washington DC, USA, 2001; pp. 63-65.

33. GAFTA 4. Available online: www.gafta.com/write/MediaUploads/Contracts/2010/4.0_CRUDE_PROTEIN.pdf (accessed on 16 November 2021).

34. ISO 5983. Available online: www.iso.org/standard/39160.html (accessed on 17 November 2021).

35. ISO 13906. Available online: www.iso.org/standard/43032.html (accessed on 17 November 2021).

36. ISO 16472. Available online: www.iso.org/standard/37898.html (accessed on 17 November 2021).

37. Van Soest, P.J. Use of detergents in the analysis of fibrous feeds: 2. A rapid method for the determination of fiber and lignin. $J$. Assoc. Off. Anal. Chem. 1990, 73, 491-497. [CrossRef]

38. Goering, H.; Van Soest, P.J. Forage fiber analysis: Apparatus, reagents, procedures and some applications. In Agricultural Handbook, 1st ed.; U.S.D.A. Agricultural Research Service: Washington, DC, USA, 1970; Volume 379, pp. 76-80.

39. Goeser, J.P.; Combs, D.K. An alternative method to assess 24-h ruminal in vitro NDF digestibility. J. Dairy Sci. 2009, 92, 3833-3841. [CrossRef]

40. Golder, H.M.; Celi, P.; Lean, I.J. Ruminal acidosis in a 21-month-old Holstein heifer. Can. Vet. J. 2014, 55, 559-564. [PubMed]

41. GAFTA 11. Available online: www.gafta.com/write/MediaUploads/Contracts/2014/method_11.0_2014.pdf (accessed on 16 November 2021).

42. ISO 5984. Available online: www.iso.org/standard/37272.html (accessed on 17 November 2021).

43. GAFTA 3. Available online: www.gafta.com/write/MediaUploads/Contracts/2014/method_3.0_2014.pdf (accessed on 16 November 2021).

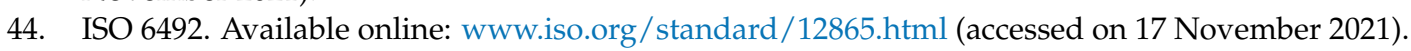

45. GAFTA 14. Available online: www.gafta.com/write/MediaUploads/Contracts/2012/14.0_SAND_ONLY_(SAND_WITHOUT_ SILICA).pdf (accessed on 16 November 2021).

46. ISO 6869. Available online: www.iso.org/standard/33707.html (accessed on 17 November 2021).

47. AOAC 965.17. Available online: www.eoma.aoac.org/methods/info.asp?ID=33502 (accessed on 16 November 2021).

48. Weiss, W.P.; Conrad, H.R.; Pierre, N.R.S. A theoretically based model for predicting total digestible nutrient values of forages and concentrates. Anim. Feed Sci. Technol. 1992, 39, 95-110. [CrossRef]

49. Nutrient Requirements of Dairy Cattle, 7th ed.; The National Academies Press: Washington, DC, USA, 2001. [CrossRef]

50. Pozebon, D.; Dressler, V.L.; Marcelo, M.C.A.; Oliveira, T.C.; Ferrao, M.F. Toxic and nutrient elements in yerba mate (Ilex paraguariensis). Food Addit. Part B Surveill. 2015, 8, 215-220. [CrossRef]

51. Goeser, J.P.; Hoffman, P.C.; Combs, D.K. Modification of a rumen fluid priming technique for measuring in vitro NDF digestibility. J. Dairy Sci. 2009, 92, 3842-3848. [CrossRef] [PubMed]

52. Liane, M.V.; Barboza-Liane, M.V.; Waszczynsky, N.J.; de Freitas, R.J.S. Microbiological evaluation of yerba-maté (Ilex paraguariensis St. Hil.). Rev. Inst. Adolfo Lutz. 2006, 65, 123-126. 
53. Albiero, G.; da Silva, P.V.; da Costa, M. Sanitary quality and diversity of culturable bacteria and yeasts in processed and in natura yerba mate (Ilex paraguariensis A.St.-Hil.). R. Bras. Bioci. 2015, 13, 90-95.

54. Norma IRAM 20517. In Yerba Mate Canchada y Yerba Mate Elaborada, 1st ed.; Análisis Microbiológicos; Instituto Argentino de Racionalización de los Materiales: Buenos Aires, Argentina, 2007.

55. INTA. 2007. Available online: Rafaela.inta.gov.ar/ingo/documentos/nutricion_valordealimentos.htm (accessed on 1 January 2020).

56. Goeser, J.P. Improvement of Rumen In Vitro NDF Digestion Techniques and Data Analysis. Ph.D. Thesis, University of Wisconsin, Madison, WI, USA, 2008.

57. Fernandez Mayer, A.E. Producción de Carne y Leche Bovina en Sistemas Silvopastoriles, 1st ed.; Bordenave, Ediciones INTA: Buenos Aires, Argentina, 2017.

58. Sniffen, C.J.; O'Connor, J.D.; Van Soest, P.J.; Fox, D.G.; Russel, J.B. A net carbohydrate and protein system for evaluating cattle diets: II Carbohydrate and protein availability. J. Anim. Sci. 1992, 70, 3562-3577. [CrossRef]

59. Van Soest, P.J. Nutritional Ecology of the Ruminant, 2nd ed.; Cornell University Press: Ithaca, NY, USA, 1994.

60. Mufarrege, D.J. Los Minerales en la Alimentación de Vacunos Para Carne en la Argentina, 1st ed.; E.E.A. INTA Mercedes: Corrientes, Argentina, 1999.

61. Sutton, J.D.; Alderman, G. The energy and protein requirements of pregnant and lactating dairy goats: The agriculture and food research council report. Livest. Prod. Sci. 2000, 64, 3-8. [CrossRef]

62. Pasinato, A.; Grigioni, G.; Alende, A. Producción Bovinos Para Carne (2013-2017), 1st ed.; Ediciones INTA: La Pampa, Argentina, 2007.

63. Baspinar, N.; Basoglu, A.; Semacan, A.; Gulersoy, E. Short term effects of dietary boron on mineral status in dairy cows. Int. J. Environ. Agric. Res. (IJOEAR) 2017, 3, 65-70. [CrossRef] 